\title{
Habitat selection of the Ortolan bunting Emberiza hortulana in Poland: predictions from large-scale habitat elements
}

Received: 4 April 2011 / Accepted: 25 November 2011/Published online: 20 December 2011

(C) The Author(s) 2011. This article is published with open access at Springerlink.com

\begin{abstract}
The Ortolan bunting Emberiza hortulana was censused in Poland during the Common Breeding Birds Monitoring Project in 2003-2009. Data from 683 monitoring polygons, covering in total more than $0.23 \%$ of the country, were used in the analysis. Based on the data and environmental information gathered in GIS databases (Corine land cover "CLC2000 and 2006" database, digital elevation model "GTOPO30" dataset, "Wordclim" dataset, and NDVI dataset), we modeled a habitat- and spatial-related variation of the Ortolan bunting's presence. Birds were recorded in $13.2 \%$ grid cells. The mean density was 0.5 individual $/ \mathrm{km}^{2}$. We modeled the spatial presence of birds using multivariate adaptive regression splines (MARS). Then models were cross-validated to check their consistency. The environment-use model shows that the Ortolan bunting prefers extensively cultivated farmland dominated by non-irrigated arable fields, small coniferous and mixed forests, complex cultivation patterns, and meadows. The preferred areas are located on lowlands in western and central parts of the country where the climate is the driest and warmest. Such a repeatable spatial pattern model of the population helped to create a predictive map of the Ortolan bunting's presence in Poland. The general rule is that the probability gradient of its presence increases from the northeastern part of the country to the central and southwestern parts of Poland. Additionally, the Ortolan bunting avoids severe continental climate and regions with dense ground-level vegetation.
\end{abstract}

\footnotetext{
J. Z. Kosicki (ه)

Department of Avian Biology and Ecology,

Faculty of Biology, Adam Mickiewicz University, ul. Umultowska 89, 61-614 Poznań, Poland

E-mail: kubako@amu.edu.pl

Tel.: + 48-61-8295617

Fax: + 48-61-8295636

P. Chylarecki

Museum and Institute of Zoology, Polish Academy of Science, ul. Wilcza 64, 00-679 Warszawa, Poland
}

Keywords Emberiza hortulana $\cdot$ Farmland - Habitat selection - Ortolan bunting · Predictive modeling

\section{Introduction}

Farmland bird populations are declining throughout Europe (Newton 2004; Donald et al. 2006). The cause is considered to be rapid changes in agricultural practice, including intensification (Brotons et al. 2004) and afforestation (Diaz et al. 1998), which result from Common Agricultural Policy (Donald et al. 2002). In Britain, changes in areas of winter stubble fields and spring-sown crops have been suggested to be the most important cause of sparrows' and finches' decline (Buckingham et al. 1999). A similar tendency has also been noticed in other countries. In Sweden and Finland, both intensified farming and abandonment of farmland in marginal regions appear to be factors contributing to the decline of sparrows (Wretenberg et al. 2006). The Ortolan bunting Emberiza hortulana is a good example of a species that suffered a strong decline in northern and central Europe. Its population has decreased in 21 out of 36 countries in the last 15 years (BirdLife International 2004). The most dramatic decline can be observed in Finland, where a loss as high as $72 \%$ of the population has been reported in the last 20 years (Vepsäläinen et al. 2005); while in Poland, for comparison, the population has decreased by $20 \%$ in the last 10 years. This is why the species is classified as SPEC 2, which means global populations concentrated in Europe of unfavorable conservation status (BirdLife International 2004).

The Ortolan bunting is a long-distance migrant species and strongly dependent on heterogeneous habitat structure dominated by semi-open agricultural land (Dale and Olsen 2002; Berg 2008) and/or open and semiopen shrubland and steppe-like habitats (Cramp and Perrins 1994). Apart from diversified habitats, the species also requires small-scale landscape elements, e.g., 
small bush islets, single large trees, barns, cowshed, and large rocks.

The studies on the Ortolan bunting's habitat selection were carried out mainly on small geographic scales (e.g., Dale and Olsen 2002; Berg 2008; Vepsäläinen et al. 2005). However, to obtain more general information on habitat use and spatial patterns vital for effective conservation, data from large geographical scales are indispensable (Atkinson et al. 2002). This notion stems from the fact that CAP causes changes on farmland throughout all EU countries (Donald et al. 2002). Unfortunately, such large-scale studies are scarce, especially those concerning birds in Central Europe (excepting Brotons et al. 2008; Kuczyński et al. 2009). The Ortolan bunting is a potentially good candidate species to be monitored in large areas, because its population has been a good indicator of general habitat loss and degradation as a consequence of farming intensification and homogenization of agricultural landscapes (sensu: Dale 2001). Besides, it is easy to detect during the breeding season because it lives in open farmland and uses exposed song posts and perching sites. Finally, remote-sensing techniques and habitat models are widely available and effective in predictive distribution modeling and biodiversity conservation (Kerr and Ostrovsky 2003; Turner et al. 2003).

The main goal of this paper is to model a spatial-, habitat-, and climate-related variation of the Ortolan bunting's breeding occurrence in Poland. Our attention is especially drawn to the issue of whether large-scale remote-sensing data could be useful in creating predictive presence maps of species whose distribution depends on small-scale landscape elements.

\section{Materials and methods}

\section{Bird data}

The data were collected for the Common Breeding Birds Monitoring Project in Poland in 2001-2007 (Chylarecki and Jawińska 2007). A total of 728 grid cells of 1 sq. $\mathrm{km}^{2}$ were chosen at random out of 311,663 available cells (Fig. 1). Each square was surveyed twice a year. The first visit took place between April 10 and May 15 starting between 6 and 7 a.m.; the second between May 16 and June 30 and also starting between 6 and 7 a.m.

The bird census consisted of two parallel 1-m transects along an east-west or north-south axis. Each transect was divided into five $200-\mathrm{m}$ sections, in which birds were noted in three distance categories $(<25$, $25-100$, and $>100 \mathrm{~m}$ ).

\section{Environmental data}

Geographical localizations, mean altitude, monthly rate of The Normalized Difference Vegetation Index (NDVI) from March to June, relative proportion of individual habitat types and climate conditions characterizing all grid cells were used in the analysis.

Altitude data come from the digital evaluation model (DEM) dataset (GTOPO30), originally provided by US Geological Survey's EROS Data Center (Sioux Falls, South Dakota). The data were converted into GRASS GIS file format (Neteler and Mitasova 2008) and re-projected to coordinate system "EPSG 4284" projection.

We obtained NDVI data from SPOT dataset (http:// free.vgt.vito.be/). NDVI, expressed as a mean monthly value, was calculated from three measurements taken every 10 days. The data was also converted into GRASS GIS file format (Neteler and Mitasova 2008) and reprojected to "EPSG 4284".

The original 37 land-cover types are recognized in the CORINE land-cover database (based on remote sensing with basic spatial units of $100 \times 100 \mathrm{~m}$ ). The database was created in 1986-1996, 2000, 2003, and 2006 from Landsat TM. The data were also converted into Mapinfo file format and re-projected to "EPSG 4284". On average, ten types of habitats were distinguished in each grid cell. The most frequent were environments classified as large-area, homogenous arable fields (AF), coniferous forest $(\mathrm{CF})$, mixed farming areas with large participation of natural vegetation (OPEN), mixed forest (MF), meadows (ME), deciduous forest (DF), shrub (SH), swamps (SW), built-up areas (BA), and water (WA).

Climate data were derived from the WorldClim database (http://www.worldclim.org), which is a set of global climate layers (climate grids) with spatial resolution of a square kilometer. All grid cells are characterized by ten variables: annual mean temperature (AMT), mean diurnal range [mean of monthly (max temp-min temp) (MDR)], temperature seasonality (standard deviation $\times 100)($ TS), max temperature of warmest month (MTWM), min temperature of coldest month (MTCM), mean temperature of wettest quarter (MTWQ), mean temperature of driest quarter (MTDQ), mean temperature of warmest quarter (MTWAQ), mean temperature of coldest quarter (MTCQ), annual precipitation (AP), precipitation of wettest quarter (PWQ), precipitation of driest month (PDM), precipitation of wettest quarter (PWQ), precipitation of warmest quarter (PWAQ), precipitation of coldest quarter (PCQ), and precipitation seasonality (coefficient of variation) (PS). The data were also converted into GRASS GIS file format (Neteler and Mitasova, 2008) and re-projected to "EPSG 4284".

Data about farming intensification were provided by Agricultural Census 2002. These variables regard the following: the number of tractors per farm 2002 (TRAC), the number of cereal combine harvesters per farm 2002 (HARV), the number of farms with cattle divided by the total number of farms (CATTLE), and the number of farms with pigs divided by the total number of farms (PIGS).

Explanatory variables, being principal components, were extracted from percentages of land-cover class, NDVI, DEM, climate and farming intensification within each study plot. PCA was used in order to remove the 


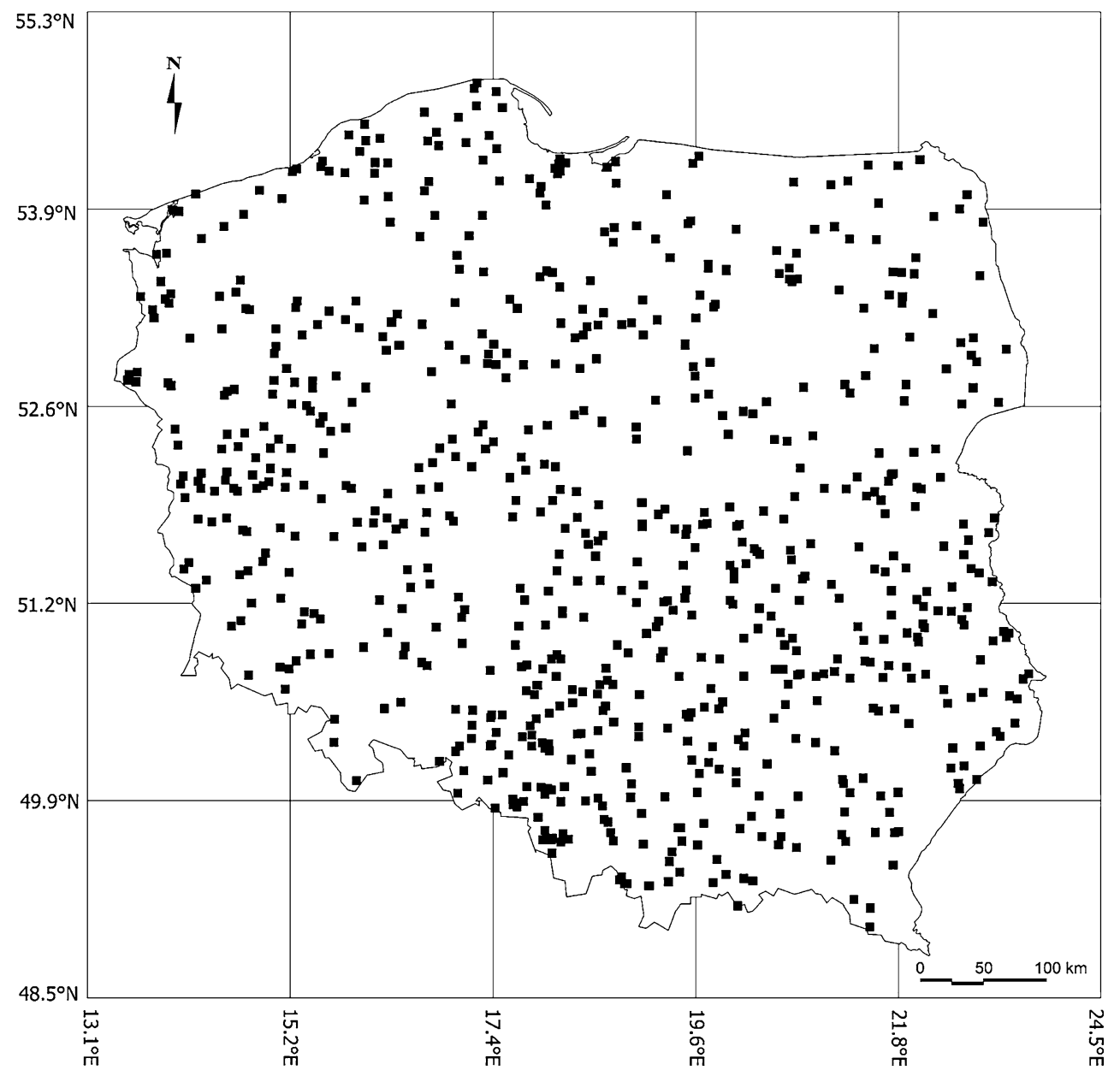

Fig. 1 Location of the study plots

strong intercorrelation inherently present within the explanatory dataset (Table 2).

\section{Habitat selectivity}

We tested the model of the Ortolan bunting's habitat selection by comparing grid cells where birds occur with grid cells where they do not occur. A grid cell where an Ortolan occurs is the one where at least one individual has been recorded in three subsequent years of the research. The differences were tested using non-parametric Mann-Whitney $U$ test with Monte Carlo permutation test (number of resamples 10,000). Statistics were performed with R 2.12.1 (R Development Core Team 2008).

\section{Prediction model fitting}

We used multivariate adaptive regression splines (MARS) function. MARS is a method of flexible nonparametric regression modeling (Friedman 1991). In this function, the approach of fitting nonlinear functions is to fit linear segments (linear basic functions) to the data. MARS function consists of a series of connected straight line segments instead of smooth curves in general additive models. Model fitting starts with forward steps that identify many knots, followed by a backward pruning routine to simplify the model. Additions and deletions are evaluated in terms of changes in residual squared errors using generalized cross-validation (GCV). Further statistical details are available in Friedman (1991) and Elith and Leathwick (2007). Knowing that environmental variables are usually correlated with one another, we used a jackknife analysis based on the area under the curve (AUC) to evaluate their significance as predictors in this model (Franklin 2010). AUC has been used extensively in evaluating species' distribution models, and measuring the model's ability to discriminate between sites where a species is present and those where it is absent.

Then, occurrence locations (dependent variable) were randomly partitioned into two subsamples: $70 \%$ was used as a training dataset, and the remaining $30 \%$ was reserved for testing the resulting (partitioned) models in each year. AUC values can indicate probability when the presence and absence sites are randomly chosen from the 
population, and the former shall have a higher predicted value than the latter. A perfect ranking achieves the maximum possible AUC of 1.0. Rankings with the AUC value above 0.75 are considered to be potentially useful (Elith et al. 2006). On this basis, a predictive map of the Ortolan bunting in Poland was made. All computations were made in R 2.12.1 (mda library, R Development Core Team 2008) and Statistica software (StatSoft 2008).

\section{Results}

\section{Population size}

Breeding populations of the Ortolan bunting were recorded in $13.2 \%$ of grid cells. The mean density was 4.8 (4.1-5.6) individuals $/ 1 \mathrm{~km}^{2}$, while the mean density on occupied plots was $10.5(9.3-11.9)$ individuals $/ 1 \mathrm{~km}^{2}$.

\section{Habitat selection model}

All the data (46 variables) were summarized using PCA (Table 2). The first principal component (Comp. 1) reflects geographical and climatological differentiation. Low values of this component indicate sites located in the north and central parts of Poland, which are relatively low on the asl, with warm and dry climate. In contrast, high values of this component appear in southern parts of Poland, being relatively high on the asl where the climate is cold and wet.

The second component (Comp. 2) also reflects geographical differentiation and habitat gradient from farmland to coniferous forest. Low values of this component are characteristic for agricultural areas with large pastures in the eastern part of the country, which tends to be cold in summer. On the other hand, high values indicate deciduous forest areas in western parts of Poland where the level of NDVI is high in the beginning of spring.

The third component (Comp. 3) is positively correlated with open agricultural land, predominantly livestock pastures. The low value of this component indicates urban areas.

The fourth component (Comp. 4) reflects a gradient from (low values) the west of the country with nonirrigated arable fields, where winters are mild and damp, to (high values) eastern parts covered by coniferous forests, characterized by harsh winters.

The fifth component (Comp. 5) is positively correlated with fallow lands located in the north.

The sixth component (Comp. 6) is positively correlated with deciduous forest and areas of damp ground.

The seventh component (Comp. 7) reflects the proportion of pastures and other classes, especially arable fields and coniferous forest.

Further components' (Comp. 8 to Comp. 14) variations have been explained to a slight degree, therefore they are not included in the analysis.

While analyzing the entire dataset (seven components) for the presence/absence of Ortolan bunting populations, we found significant differences in five environmental predictors. The differences are noticeable between such environmental predictors as: Comp. 1, Comp. 2, Comp. 4, Comp. 6, Comp. 7 (Table 1) that describe quite unique conditions mostly limited to the extensively cultivated farmland, dominated by non-irrigated arable fields, small coniferous and mixed forests, complex cultivation patterns and meadows. The preferred areas are localized in lowlands in western and central parts of the country, where the climate is the driest and the warmest (Table 1).

\section{Habitat prediction model}

The MARS model with all components had a moderate predictive capacity (GCV $0.94 \pm 0.006$ ). However, the model containing only three components, after forward selection had a better ability (GCV $0.23 \pm 0.001)$.

The jackknife analysis shows that the most important variables are Comp. 1, Comp. 2, Comp. 7, which represent the highest AUC values for the Ortolan bunting habitat prediction [Fig. 2, Selected (Comp. 1, 2, 7)].

For models with only one component, the highest AUC regarded Comp. 1, Comp. 2, Comp. 7 (Fig. 2 "with only one variable"). Models with Comp. 3-6 only had a relatively low AUC (Fig. 2 "with only one variable"). So models with all components, in which Comp. 1,2 , or 7 respectively were removed, had low AUC (Fig. 2 "without variable").

We find no differences between the observed and the predicted occurrence of the Ortolan bunting $\left(\chi^{2}=1.12\right.$, $p=0.54)$.
Table 1 Comparison of environmental structure variables between grid cells where Ortolan buntings are present (OB-E, $n=97)$ and absent (OB-N, $n=631)$

\begin{tabular}{|c|c|c|c|c|c|}
\hline Variable & OB-E (mean \pm SE) & $\mathrm{OB}-\mathrm{N}($ mean $\pm \mathrm{SE})$ & $Z$ & $p$ value & $\begin{array}{l}p \text { value } \\
\text { (permutation) }\end{array}$ \\
\hline Comp. 1 & $-0.29 \pm 0.60$ & $0.42 \pm 0.98$ & -2.84 & 0.05 & $<0.01$ \\
\hline Comp. 2 & $-0.41 \pm 0.60$ & $0.075 \pm 1.05$ & -4.27 & $<0.01$ & $<0.01$ \\
\hline Comp. 3 & $0.11 \pm 0.62$ & $-0.056 \pm 0.88$ & -1.50 & 0.13 & 0.14 \\
\hline Comp. 4 & $-0.25 \pm 0.69$ & $-0.039 \pm 0.99$ & -2.22 & 0.02 & 0.02 \\
\hline Comp. 5 & $0.28 \pm 0.59$ & $0.20 \pm 0.90$ & -0.25 & 0.80 & 0.91 \\
\hline Comp. 6 & $-0.29 \pm 0.81$ & $-0.09 \pm 0.96$ & -2.88 & $<0.01$ & $<0.01$ \\
\hline Comp. 7 & $-0.40 \pm 0.68$ & $0.08 \pm 0.95$ & -4.89 & $<0.01$ & $<0.01$ \\
\hline
\end{tabular}

Significant values are given in bold 


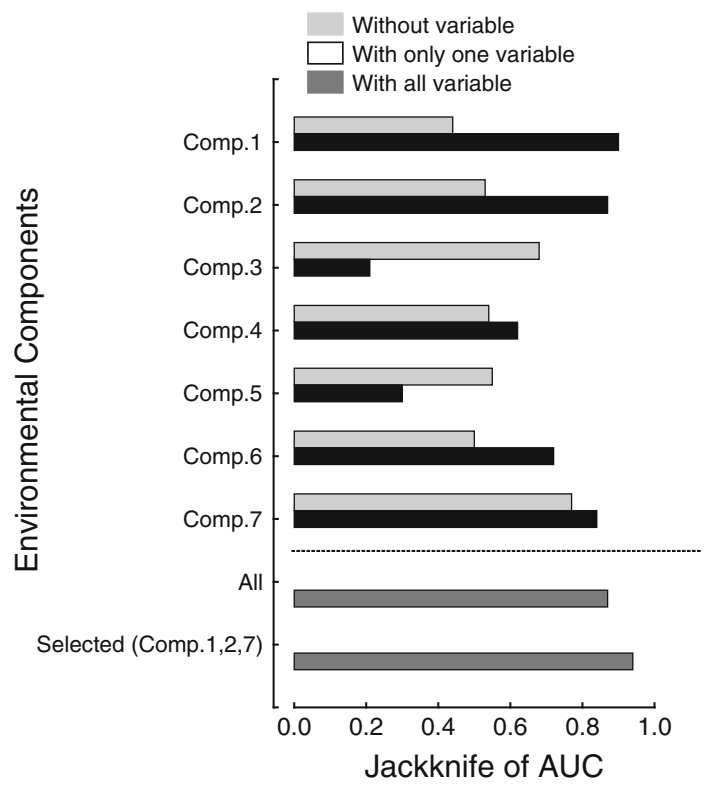

Fig. 2 The jackknife analysis of variables' significance as predictors in the Ortolan bunting model. AUC the area under the curve. "Without variables" (pale grey) is AUC for the total model in which a given component is not included, "with only one variable" (black) is a model with only one component, "with all variables" (dark grey) is a total model with all components (all) and a selected model [selected (Comp. 1, 2, 7)] including only three components

With the above facts taken into consideration, we created a predictive habitat map for the Ortolan bunting (Fig. 3). According to the model, the preferred environmental components are found in $17.7 \%$ of the country, where the probability to encounter an Ortolan bunting is the highest, varying from 0.44 to 1 . Habitats that are particularly preferred are the ones associated with major extensively cultivated farmlands and complex cultivation patterns, such as large non-irrigated arable fields, coniferous and mixed forests. The Ortolan bunting tends to avoid regions of wet and cold climate. The lowest densities are at higher elevations as well as in areas that are the coldest, i.e., NE part of the country (Fig. 3).

\section{Discussion}

The present analysis shows that with regard to large-scale habitat elements, Ortolan buntings in Poland prefer dry and warm-weather conditions and large non-irrigated arable fields and meadows with coniferous and mixed forest. We have found out that the presence probability gradient increases from the north and north-east to the central and south-west parts of Poland. The gradient of presence established in this study falls within the broad range of density gradients presented by other authors, where density increases from 0.03 to 0.1 individual $/ \mathrm{km}^{2}$ in the northwestern part of the country to 1.8 individual/ $\mathrm{km}^{2}$ in the central-southern part (Goławski and Dombrowski 2002; Tryjanowski et al. 2009).

It appears that habitat preferences of the Ortolan bunting differ spatially. In northern and central Europe, breeding areas are associated with semi-open agricultural land (Cramp and Perrins 1994; Berg 2008), whereas in Mediterranean regions, the Ortolan bunting occurs in open and semi-open shrub lands and steppe (Cramp and Perrins 1994). More detailed analyses show that in Central Europe structures with small fields close to edge habitats and solitary trees are most important factors for choosing nest sites, song posts, and foraging habitats (Goławski and Dombrowski 2002; Dale and Olsen 2002). In Norway, most breeding territories were found on forest-fire sites where there were no areas with dense ground-level vegetation (Nævra 2002; Santos et al. 2002). In Switzerland and Catalonia, bare ground was identified as an important variable in habitat selection by the species (Menz et al. 2009). Finally, according to our study, $11 \%$ of the Ortolan bunting's predictive localizations are situated in tectonic foreland in the southwest of the country where mean asl is $365 \mathrm{~m}$. This fact probably does not reflect any topographic preferences, but it is worth noticing that there are large areas of bare land. A possible explanation why all these habitats are chosen could be a general rule that the Ortolan bunting prefers mosaic habitats with low vegetation as its foraging area and nest site (Nævra 2002; Vepsäläinen et al. 2005). However, studies conducted on small spatial scales show that not only heterogeneous habitats are important, but small environmental elements are as well, such as small bush islets, single large trees, barns, cowshed, and large rocks. This is because these areas provide song posts and perching sites, but above all feeding and breeding places (von Lang et al. 1990; Kujawa and Tryjanowski 2000; Tryjanowski 2001). It is worth noting that farmland landscapes of this type are also ideal for other declining farmland birds (Tucker and Evans 1997), including high-priority conservation species, such as Red-Backed Shrike Lanius collurio, Northern Wheatear Oenanthe oenanthe, European Starling Sturnus vulgaris, White Wagtail Motacilla alba and Fieldfare Turdus pilaris, Corn Bunting Miliaria calandra, and other Emberiza spp. (e.g., Pärt and Söderström 1999; Brambilla et al. 2008). These landscape elements, namely heterogeneous habitats and small environmental elements, can be likened to extensive farming practices involving small-parcel farming and mixed livestock farming (Donald et al. 2002). The onset of agricultural changes, including reduced overall habitat heterogeneity caused by an increase in monocultures, large-scale cropping, and specialization on farming, brings about reduced heterogeneity of habitats and removal of small environmental elements (Fuller et al. 1995). For example, the fact that briar hedges along fields and ditches were removed influenced a decrease in the Red-Backed Shrike population, and so was the case with grassy field margins whose elimination negatively effected the population of S. communis (Mason and MacDonald 2000). Additionally, reconstructing old anthropogenic elements, e.g., barns or buildings, according to CAP requirements caused a dramatic decline of the Barn Sparrow Hirundo rustica population (Møller 2001). 


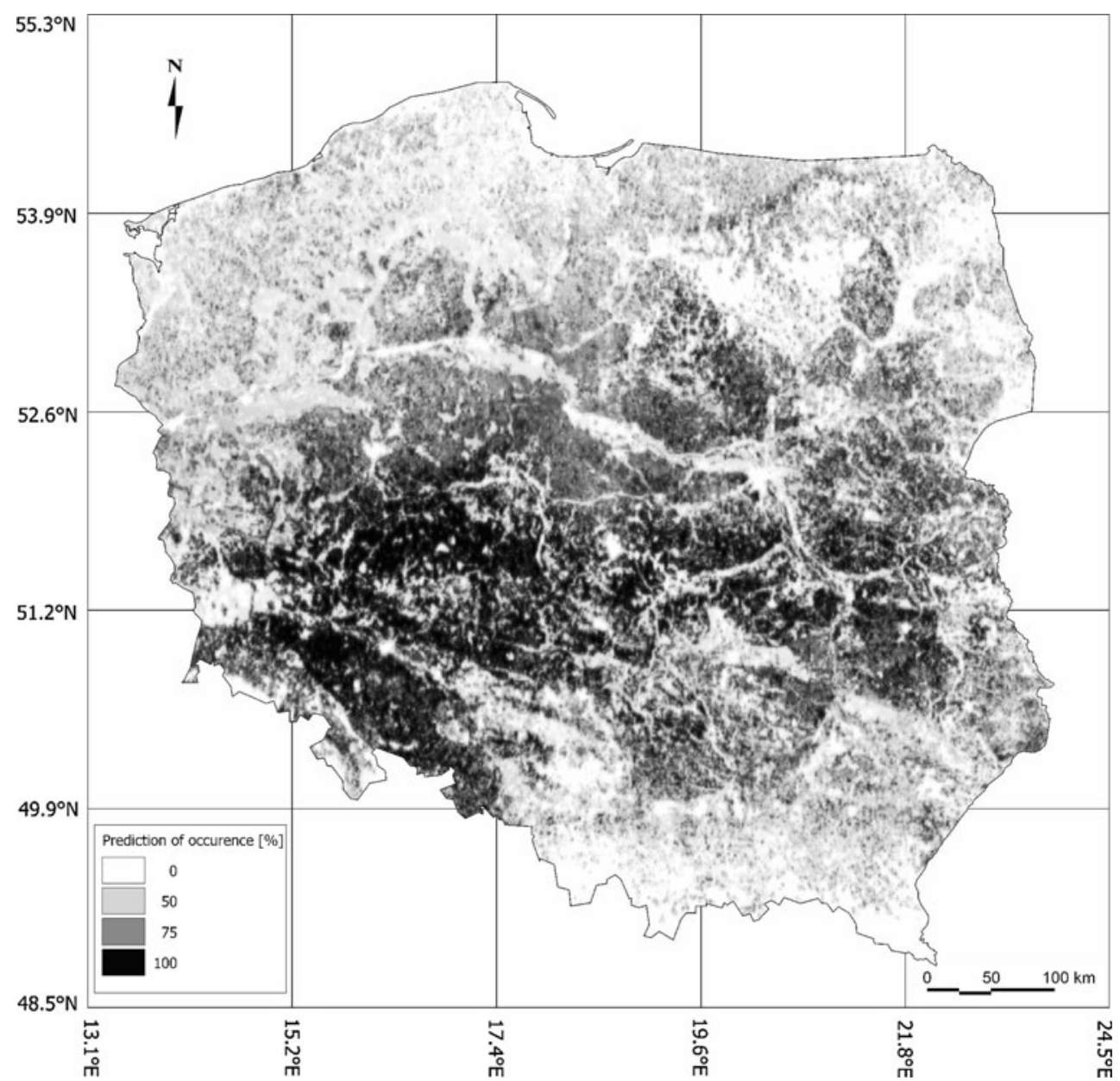

Fig. 3 Predicted presence of breeding populations of the Ortolan bunting in Poland. The map shows joint influence of both spatial and habitat variation on the population's presence

These progressive land-use changes may be affecting the Ortolan bunting and other open-habitat species populations elsewhere in Europe through a reduction of optimal habitat structures and food accessibility. This is why it is necessary to carry out further work that will shed more light on the suggested causes of the declines of bird populations.

Our study concentrates on large-scale habitat elements. According to our dataset, small environmental elements' influence on the Ortolan bunting population is weakened by the fact that different types of habitats are not defined in the Corine Land Cover dataset. We suspect (but have not yet analyzed) that the high efficiency of our predictive model shows that on a large-scale small-scale habitat elements are of low importance. A more likely explanation could be that aggregations of small-scale elements are often located on large field areas (e.g., Storch et al. 2003).

Another important variable in the model of the Ortolan bunting's presence is weather. However, its role is generally less clear when compared to habitat preferences. We suspect that ambient temperature indirectly influences food availability and nest sites (White 2008).
Indeed, we found a simple correlation among high MTWQ, low annual precipitation (AP), precipitation seasonality (PS), low precipitation of the driest quarter (PDQ), and lose ground-level vegetation (all $p<0.05$ ). So in his case variables describing the climate have indirect influence because they only determine places with low vegetation.

To conclude, sensing data can reveal important associations between species distribution and habitats, but it is insufficient for revealing all of the important ecological factors that can affect species' distribution when considering habitats on a finer scale. On a smaller scale, such data cannot replace - at least as far as conservation is concerned - the painstaking field study of habitat requirements for individual species (Storch et al. 2003).

The distribution map based on monitoring data should be considered to be the first step in achieving an accurate abundance model of the Ortolan bunting. Future abundance models should include small habitat elements, which are important for breeding, foraging, and singing of this species. What is more important, by applying models created for specialized farmland-dwelling 


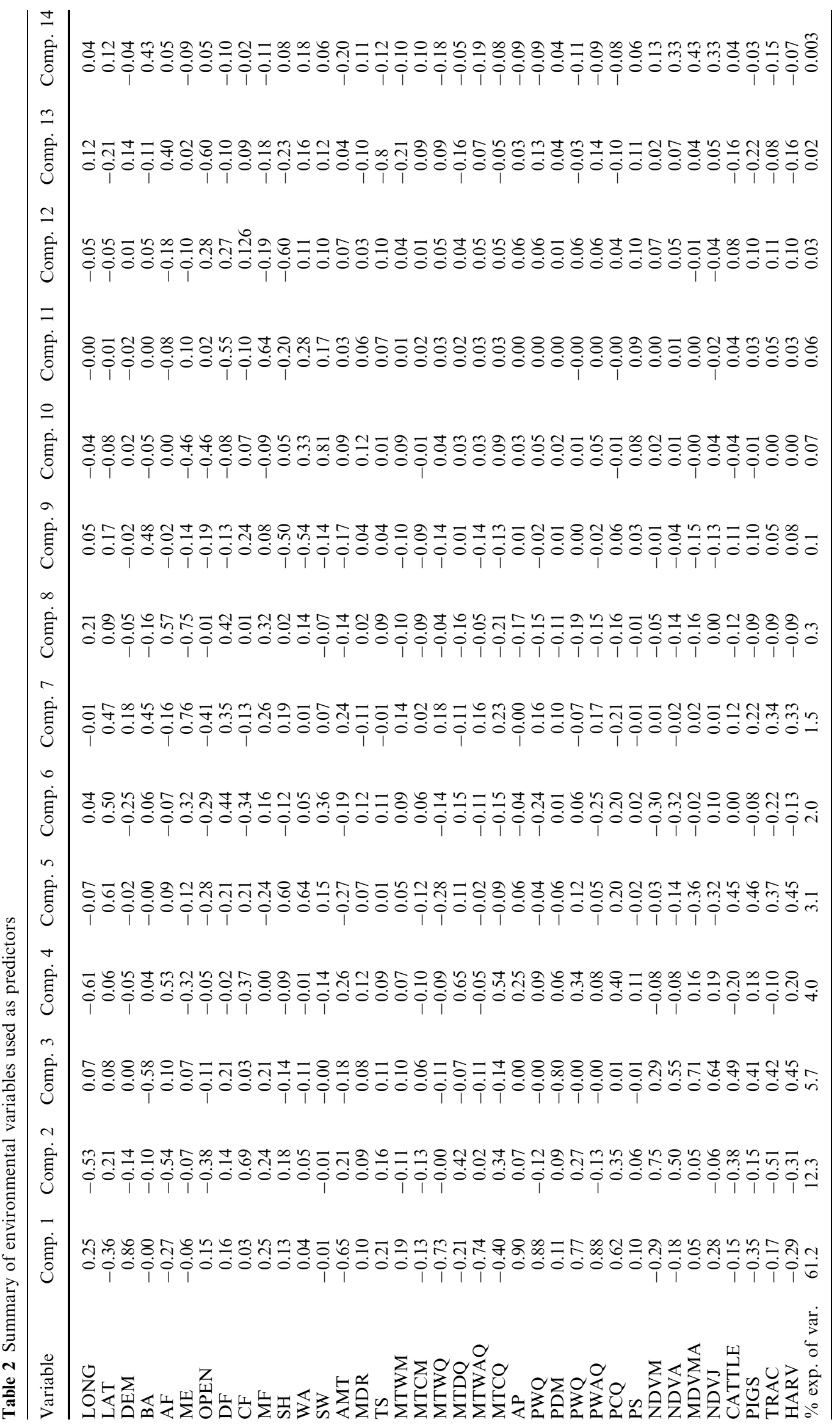


species, we will be able to assess a representative habitat for future direct conservation planning on the landscape scale.

Acknowledgments We wish to express our gratitude to observers who collected data in the field. The full list of their names can be found at http://main3.amu.edu.pl/ kubako/tsr/. We want to thank Justyna Grześkowiak for her linguistic assistance. The study was supported by MNiSW grant NN304 025936.

Open Access This article is distributed under the terms of the Creative Commons Attribution Noncommercial License which permits any noncommercial use, distribution, and reproduction in any medium, provided the original author(s) and source are credited.

\section{Appendix}

See Table 2.

\section{References}

Atkinson PW, Fuller RJ, Vickery JA (2002) Large-scale patterns of summer and winter bird distribution in relation to farmland type in England and Wales. Ecography 25:466-480

Berg A (2008) Habitat selection and reproductive success of Ortolan Buntings Emberiza Hortulana on farmland in central Sweden - the importance of habitat heterogeneity. Ibis 150:565-573

BirdLife International (2004) Birds in Europe: population estimates, trends and conservation status. BirdLife International, Cambridge

Brambilla M, Guidali F, Negri I (2008) The importance of an agricultural mosaic for Cirl Buntings Emberiza cirlus in Italy. Ibis 150:628-632

Brotons L, Mañosa S, Estrada J (2004) Modelling the effects of irrigation schemes on the distribution of steppe birds in Mediterranean farmland. Biodivers Conserv 3:1039-1058

Brotons L, Herrando S, Pons P (2008) Wildfires and the expansion of threatened farmland birds: the Ortolan Bunting Emberiza hortulana in Mediterranean landscapes. J Appl Ecol 45:1059-1066

Buckingham DL, Evans AD, Morris AJ, Orsman CJ, Yaxley R (1999) Use of set-aside land in winter by declining farmland bird species in the UK. Bird Study 46:157-169

Chylarecki P, Jawińska D (2007) Monitoring Pospolitych Ptaków Lęgowych. Raport z lat 2005-2006. OTOP, Warszawa

Cramp S, Perrins CM (1994) The birds of the Western Palearctic, vol. 9. Oxford University Press, Oxford

Dale S (2001) Female-biased dispersal, low female recruitment, unpaired males, and the extinction of small and isolated bird populations. Oikos 92:344-356

Dale S, Olsen BFG (2002) Use of farmland by Ortolan buntings (Emberiza hortulana) nesting on a burned forest area. J Ornit 143:133-144

Diaz M, Carbonell R, Santos T, Telleria JL (1998) Breeding bird communities in pine plantations of the Spanish plateaux: biogeography, landscape and vegetation effects. J Appl Ecol 35:562-574

Donald PF, Pisano G, Rayment MD, Pain DJ (2002) The Common Agricultural Policy, EU enlargement and the conservation of Europe's farmland birds. Agric Ecosyst Environ 89:167-182

Donald PF, Sanderson FJ, Burfield IJ, van Bommel FPJ (2006) Further evidence for a continent-wide impact of agricultural intensification on European farmland birds 1990-2000. Agric Ecosys Environ 116:189-196
Elith J, Leathwick J (2007) Predicting species distributions from museum and herbarium records using multiresponse models fitted with multivariate adaptive regression splines. Divers Distrib 13:265-275

Elith J, Graham CH, Anderson RP, Dudík M, Ferrier S, Guisan A, Hijmans RJ, Huettmann F, Leathwick JR, Lehmann A, Li J, Lohmann LG, Loiselle BA, Manion G, Moritz C, Nakamura M, Nakazawa Y, McC Overton J, MOPeterson AT, Phillips SJ, Richardson K, Scachetti-Pereira R, Schapire RE, Soberón J, Williams S, Wisz MS, Zimmermann NE (2006) Novel methods improve prediction of species' distributions from occurrence data. Ecography 29:129-151

Franklin J (2010) Mapping species distributions. Spatial inference and prediction. Cambridge University Press, Cambridge

Friedman JH (1991) Multivariate adaptive regression splines (with discussion). Ann Stat 19:1-141

Fuller RJ, Gregory RD, Gibbons DW, Marchant JH, Wilson JD, Baillie SR, Carter N (1995) Population declines and range contractions among lowland farmland birds in Britain. Conserv Biol 9:1425-1441

Goławski A, Dombrowski A (2002) Habitat use of Yellowhammers Emberiza citrinella, Ortolan Buntings Emberiza hortulana, and Corn Buntings Miliaria calandra in farmland of east-central Poland. Ornis Fenn 79:164-172

Kerr JT, Ostrovsky M (2003) From space to species: ecological applications for remote sensing. Trends Ecol Evol 18:299-305

Kuczyński L, Rzępała M, Goławski A, Tryjanowski P (2009) The wintering distribution of Great Grey Shrike Lanius excubitor in Poland: predictions from a large-scale historical survey. Acta Ornithol 44:159-166

Kujawa K, Tryjanowski P (2000) Relationships between the abundance of breeding birds in Western Poland and structure of agricultural landscape. Acta Zool Hung 46:103-114

Mason CF, MacDonald SM (2000) Influence of landscape and landuse on the distribution of breeding birds in farmland in eastern England. J Zool Soc Lond 251:339-348

Menz MHM, Brotons L, Arlettaz R (2009) Habitat selection by Ortolan Buntings Emberiza hortulana in post-fire succession in Catalonia: implications for the conservation of farmland populations. Ibis 151:752-761

Møller AP (2001) The effect of dairy farming on barn swallow Hirundo rustica abundance, distribution and reproduction. J Appl Ecol 38:378-389

Nævra A (2002) The fateful hour of the Ortolan Bunting (Emberiza hortulana). Vår Fuglefauna 25:62-81

Neteler M, Mitasova H (2008) Open source GIS: a GRASS GIS approach, 3rd edn. Springer, New York

Newton I (2004) The recent declines of farmland bird populations in Britain: an appraisal of causal factors and conservation action. Ibis 146:579-600

Pärt T, Söderström B (1999) The effects of management regimes and location in landscape on the conservation of farmland birds breeding in semi-natural pastures. Biol Conserv 90:113-123

R Development Core Team (2008) R: a language and environment for statistical computing. R Foundation for Statistical Computing, Vienna, Austria

Santos T, Tellería JL, Carbonell R (2002) Bird conservation in fragmented Mediterranean forests of Spain: effects of geographical location, habitat and landscape degradation. Biol Conserv 105:113-125

StatSoft (2008) STATISTICA (data analysis software system), version 7.1. http://www.statsoft.com

Storch D, Konvička M, Beneš J, Martinková J, Gaston KJ (2003) Distribution patterns in butterflies and birds of the Czech Republic: separating effects of habitat and geographic position. J Biogeogr 30:1195-1205

Tryjanowski P (2001) Song sites of buntings Emberiza citrinella, E. hortulana and Miliaria calandra in farmland: microhabitat differences. In: Tryjanowski P, Osiejuk TS, Kupczyk M (eds) Bunting studies in Europe. Bogucki Wyd. Nauk., Poznań, pp 33-41 
Tryjanowski P, Kuźniak S, Kujawa K, Jerzak L (2009) Ekologia ptaków krajobrazu rolniczego. Bogucki Wyd. Nauk., Poznań

Tucker GM, Evans MI (1997) Habitats for birds in Europe: a conservation strategy for the wider environment. Birdlife International, Cambridge

Turner W, Spector S, Gardiner N, Fladeland M, Sterling E Steininger M (2003) Remote sensing for biodiversity science and conservation. Trends Ecol Evol 18:306-314

Vepsäläinen V, Pakkala T, Piha M, Tiainen J (2005) Population crash of the Ortolan bunting Emberiza hortulana in agricultural landscapes of southern Finland. Ann Zool Fenn 42:91-107 von Lang M, Bandorf H, Dornberger W, Klein H, Mattern U (1990) Breeding distribution, population, development and ecology of the Ortolan bunting (Emberiza hortulana) in Frankonia. Okologie der Vogel 12:97-126

White TCR (2008) The role of food, weather and climate in limiting the abundance of animals. Biol Rev 83:227-248

Wretenberg J, Lindström $\AA$, Svensson S, Thierfelder T, Pärt T (2006) Population trends of farmland birds in Sweden and England: similar trends but different pattern in agricultural intensification. J Appl Ecol 43:1110-1120 